\title{
PENGARUH KOMPENSASI KARYAWAN, MORALITAS INDIVIDU, KEADILAN ORGANISASI DAN SISTEM PENGENDALIAN INTERN TERHADAP KECURANGAN (Studi Empiris Pada PT. Bank Central Asia Tbk. Kantor Cabang Pembantu Ruko Roxy Mas Jakarta)
}

\author{
Jahormin Simarmata, SE., Ak., M.Ak \\ Intan Kartika Sari \\ jahormin.simarmata@gmail.com, intankartika20@gmail.com \\ Fakultas Ekonomi \& Bisnis - Program Studi Akuntansi \\ Universitas Satya Negara Indonesia
}

\begin{abstract}
ABSTRAK
Penelitian ini bertujuan untuk mengetahui pengaruh kompensasi karyawan, moralitas individu, keadilan organisasi dan sistem pengendalian intern terhadap kecurangan. Populasi dalam penelitian ini adalah seluruh karyawan PT. Bank Central Asia Tbk. Kantor Cabang Pembantu Ruko Roxy Mas Jakarta. Dalam penelitian ini menggunakan metode purposive sampling dengan responden sebanyak 49 responden. Data yang digunakan dalam penelitian ini dikategorikan sebagai data primer. Data dikumpulkan melalui kuesioner. Data diolah dan dianalisis menggunakan program aplikasi IBM Statistic Program Social Science (SPSS) versi 22.0. Hasil pengujian menunjukkan bahwa secara parsial kompensasi karyawan, moralitas individu, keadilan organisasi dan sistem pengendalian intern berpengaruh signifikan terhadap kecurangan, serta terdapat pengaruh simultan kompensasi karyawan, moralitas individu, keadilan organisasi dan sistem pengendalian intern terhadap kecurangan.

Kata kunci : Kompensasi Karyawan, Moralitas Individu, Keadilan Organisasi, Sistem Pengendalian Intern, Kecurangan.
\end{abstract}

\section{ABSTRACT}

This research aims to determine the effect of employee compensation, individual morality, organizational justice and internal control systems on fraud. The population in this research were all employees at PT. Bank Central Asia Tbk. Ruko Roxy Mas Sub-Branch Office in Jakarta. In this research using a purposive sampling method with 49 respondents. The data used in this research are categorized as primary data. Data collected through a questionnaire. Data were processed and analyzed using the IBM Statistics Social Program (SPSS) application program version 22.0. The results of research show that partially employee compensation, individual morality, organizational justice and internal control systems have a significant effect on fraud, and simultaneously that the employee compensation, individual morality, organizational justice and internal control systems have a significant effect on fraud.

Keywords : Employee Compensation, Individual Morality, Organizational Justice, Internal Control System, Fraud. 


\section{PENDAHULUAN}

\section{Latar Belakang}

Seiring dengan perkembangan zaman yang semakin maju membuat Masyarakat lebih memilih untuk menyimpan uang di bank karena banyak manfaat yang didapat dengan menyimpan uang di bank, salah satunya yaitu rasa aman dan memudahkan masyarakat dalam melakukan transaksi bisnis yang dijalankan. Salah satu aspek berkembangnya dunia perbankan adalah beragamnya produk-produk perbankan yang menarik dengan teknologi yang modern sehingga Masyarakat bisa memilih untuk transaksi keuangan dan investasi dengan cepat dan tepat sesuai dengan kebutuhan mereka.

Walaupun sudah dibentuk sistem pengawasan dalam perbankan, operasional dalam suatu perbankan dapat menyebabkan manajemen puncak memiliki keterbatasan dalam berkomunikasi dengan unit yang terkait untuk mengetahui kinerja para karyawannya. Hal ini menyebabkan sebuah kesulitan dalam mengetahui apakah prosedur-prosedur yang ditetapkan oleh suatu perbankan sudah ditaati oleh para karyawannya. Ini menjadi keterbatasan antara manajemen puncak dengan operasional untuk mengetahui kelemahan dalam suatu pengawasan yang telah dibuat sehingga dapat menyebabkan terjadinya penyimpangan dan kecurangan, seperti pencurian, penggelapan, pemalsuan, dan lain-lain.

Menurut Association of Certified Fraud Examiners (ACFE) dalam Report to the Nation on Occupational Fraud and Abuse (ACFE, 2016) ditemukan sebesar $12 \%$ kasus financial statement fraud yang terjadi pada perusahaan yang bergerak di bidang perbankan dan pelayanan keuangan, dimana jumlah persentase ini lebih tinggi dibandingkan dengan rata-rata kasus financial statement fraud yang terjadi dalam berbagai bidang industri sejumlah 9.6\%. Hal ini memberikan gambaran bahwa industri perbankan dan layanan keuangan memiliki risiko yang besar sebagai tempat terjadinya kasus kecurangan pada laporan keuangan. (Centhya Wati, 2017:157).

Beberapa faktor yang dapat mempengaruhi seseorang melakukan kecurangan seperti kompensasi karyawan, moralitas individu, keadilan organisasi dan sistem pengendalian intern dan lainnya.

\section{Perumusan Masalah}

Berdasarkan latar belakang masalah yang telah diuraikan sebelumnya, maka perumusan masalah yang dapat diidentifikasi dalam penelitian ini antara lain :

1. Apakah kompensasi karyawan berpengaruh terhadap kecurangan?

2. Apakah moralitas individu berpengaruh terhadap kecurangan ?

3. Apakah keadilan organisasi berpengaruh terhadap kecurangan ?

4. Apakah sistem pengendalian intern berpengaruh terhadap kecurangan ?

5. Apakah kompensasi karyawan, moralitas individu, keadilan organisasi dan sistem pengendalian intern berpengaruh simultan terhadap kecurangan ?

\section{Tujuan dan Kegunaan Penelitian}

Tujuan dalam penelitian ini adalah untuk mengetahui pengaruh kompensasi karyawan, moralitas individu, keadilan organisasi, dan sistem pengendalian intern terhadap kecurangan baik dengan masing-masing (parsial) maupun dengan cara 
bersama-sama (simultan), serta untuk mengetahui apakah penelitian ini memiliki konsistensi yang sama dengan penelitian sebelumnya.

Kegunaan penelitian ini diharapkan dapat memberikan sarana untuk menambah wawasan dan pengetahuan mengenai ilmu yang sedang diteliti khususnya mengenai pengaruh kompensasi karyawan, moralitas individu, keadilan organisasi dan sistem pengendalian intern terhadap kecurangan. Bagi Pembaca, dapat memperoleh dan menambah ilmu pengetahuan. Bagi Calon Peneliti, penelitian ini diharapkan dapat digunakan sebagai referensi tambahan bagi peneliti selanjutnya yang akan mengadakan kajian yang lebih luas terkait dengan penelitian ini.

Hasil penelitian ini diharapkan dapat memberikan informasi mengenai pengaruh kompensasi karyawan, moralitas individu, keadilan organisasi dan sistem pengendalian intern terhadap kecurangan. Kecurangan dapat terjadi didalam dunia perbankan sehingga peneliti berharap dapat memberikan masukan untuk perbaikan dan perubahan yang positif bagi perusahaan.

\section{LANDASAN TEORI}

\section{Kompensasi Karyawan}

Menurut Garry Desler (1996) kompensasi adalah "Semua bentuk penggajian atau ganjaran mengalir kepada pegawai dan timbul dari kepegawaiannya mereka" (Waseso, 2017:103). Sedangkan menurut T Hani Handoko (1995) kompensasi adalah "Segala sesuatu yang diterima para karyawan sebagai balas jasa untuk kerja mereka" (Waseso, 2017:103).

Menurut Ivancevich (1995) dalam (Kadarisman, 2016:6) kompensasi adalah fungsi Human Resouce Management (HRM) yang berhubungan dengan setiap jenis reward yang diterima individu sebagai balasan atas pelaksanaan tugas-tugas organisasi. Pegawai menukarkan tenaganya untuk mendapatkan reward finansial maupun nonfinansial.

\section{Moralitas Individu}

Moral menurut Kamus Besar Bahasa Indonesia adalah "tentang baik atau buruk yang diterima umum mengenai akhlak dan budi pekerti, kondisi mental yang memengaruhi seseorang menjadi tetap bersemangat, berani, disiplin dan sebagainya" (Agus Santoso, 2012:82).

Moralitas (dari kata sifat latin moralis) mempunyai arti yang pada dasarnya sama dengan "moral", artinya segi moral suatu perbuatan baik atau buruk. Moralitas adalah sifat moral atau keseluruhan asas dan nilai yang berkenaan dengan baik dan buruk. (Bertens, 1993) dalam (Ranti, 2016).

\section{Keadilan Organisasi}

Keadilan berasal dari kata adil, menurut Kamus Besar Bahasa Indonesia adil adalah "tidak sewenang-wenang, tidak memihak, tidak berat sebelah. Adil terutama mengandung arti bahwa suatu keputusan dan tindakan didasarkan atas normanorma yang objektif" (Agus Santoso, 2012:85).

Keadilan organisasi menurut (Khatri, et al. 1999) dalam Mariani (2011) dalam Lisa Amelia Herman (2013) adalah istilah untuk mendeskripsikan kesamarataan atau keadilan ditempat kerja yang berfokus bagaimana para pekerja 
menyimpulkan apakah mereka diperlakukan secara adil dalam pekerjaannya dan bagaimana kesimpulan tersebut kemudian mempengaruhi variabel-variabel lain yang berhubungan dengan pekerjaan.

\section{Sistem Pengendalian Intern}

Sistem pengendalian intern menurut (Hery, 2017:132) adalah kebijakan dan prosedur yang dirancang untuk memberikan kepastian yang layak bagi manajemen bahwa perusahaan telah mencapai tujuan dan sasarannya. Manajemen memiliki tiga tujuan umum dalam merancang sistem pengendalian internal yang efektif yaitu, keandalan pelaporan keuangan, efisiensi dan efektivitas operasi dan ketaatan pada hukum dan peraturan. Untuk mencapai tujuan tersebut, maka terdapat elemen Sistem Pengendalian Intern, yaitu : Lingkungan Pengendalian, Penilaian Risiko, Aktivitas Pengendalian Internal, Informasi dan Komunikasi Akuntansi, dan Pemantauan

\section{Kecurangan}

Definisi Fraud Menurut Black Law Dictionary (8th Ed) dalam (Diaz Priantara, 2013:3-4) adalah suatu perbuatan sengaja untuk menipu atau membohongi, suatu tipu daya atau cara-cara yang tidak jujur atau mengambil atau menghilangkan uang, harta, hak yang sah milik orang lain baik karena suatu tindakan atau dampak yang fatal dari tindakan itu sendiri. Sedangkan yang lebih umum, menurut the Association of Certified Fraud Examiner (ACFE) dalam (Diaz Priantara, 2013:5) adalah mendefinisikan Fraud sebagai Segala upaya untuk mengelabui atau memperdaya pihak lain untuk mendapatkan manfaat. Fraud meliputi banyak ragam tindakan penyelewengan atau perbuatan yang tidak sesuai hukum untuk memperoleh manfaat ekonomis tidak selalu materi secara langsung.

\section{METODOLOGI PENELITIAN}

\section{Tempat dan Waktu Penelitian}

Penelitian ini dilaksanakan pada PT. Bank Central Asia Tbk. Kantor Cabang Pembantu Ruko Roxy Mas Jakarta yang berlokasi di Ruko Roxy Mas Blok C5 No. 6-8 Jl. KH. Hasyim Ashari No 125, Jakarta Pusat 10150, pada bulan Mei sampai Juli 2020.

\section{Desain Penelitian}

Desain penelitian yang digunakan adalah penelitian kausal (Causal Research), yaitu penelitian yang bersifat sebab dan akibat. Digunakan untuk mengetahui pengaruh antara satu atau lebih variabel bebas (Independent Variabel): Kompensasi Karyawan, Moralitas Individu, Keadilan Organisasi, dan Sistem Pengendalian Intern terhadap variabel terikat (Dependent Variabel) Kecurangan. Untuk mempermudah pemahaman, maka dibuat gambar kerangka penelitian berikut . 
Variabel Independen

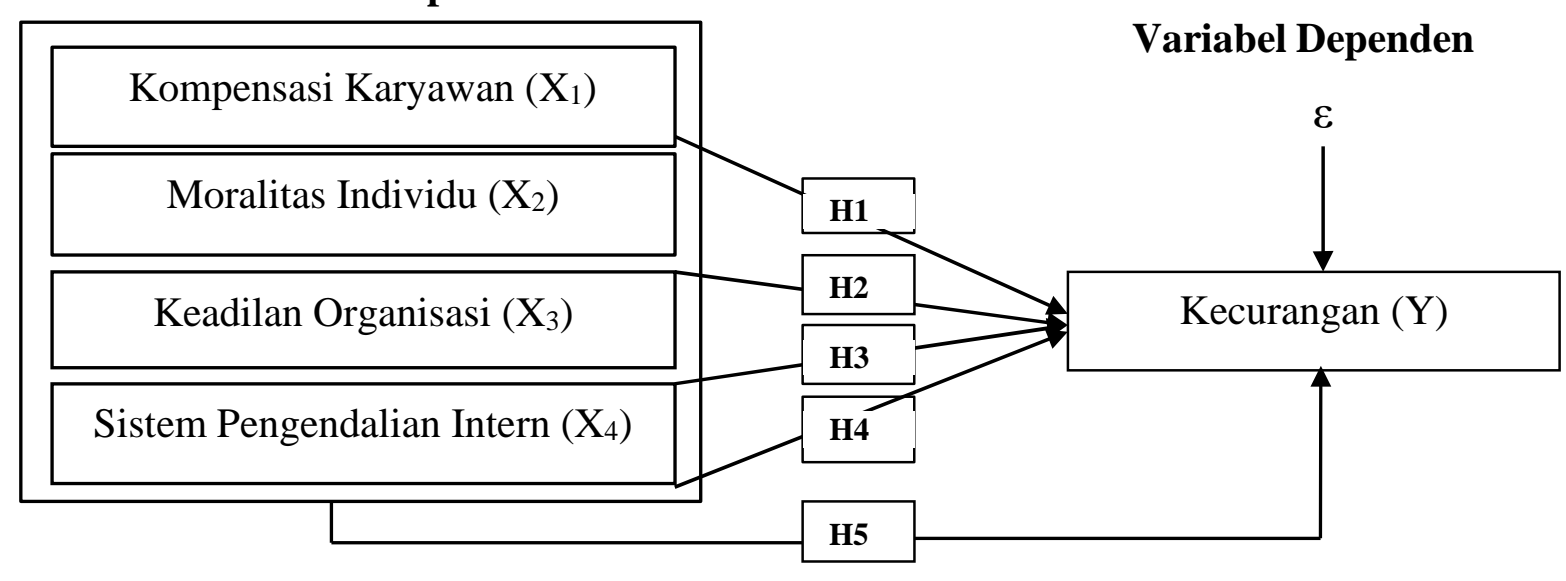

Gambar : Kerangka Penelitian

\section{Jenis Data}

Jenis data yang digunakan dalam penelitian ini adalah data primer, yaitu sumber data yang diperoleh langsung dari objek yang diteliti untuk mengukur variabel independen (Kompensasi Karyawan, Moralitas Individu, Keadilan Organisasi dan Sistem Pengendalian Intern), dan variabel dependen (Kecurangan) yang diambil dari hasil pengujian kuesioner.

\section{Populasi dan Sampel Penelitian}

Populasi dalam penelitian ini adalah karyawan yang bekerja di PT. Bank Central Asia Tbk. Kantor Cabang Pembantu Ruko Roxy Mas Jakarta.

Sampel dalam penelitian ini diambil dengan menggunakan metode purposive sampling. Kreteria responden yang dijadikan sampel dalam penelitian ini adalah sebagai berikut :

1. Bagian operasional, bagian audit internal, bagian finance, dan bagian HRD.

2. Telah berkerja minimal 1 tahun.

\section{Variabel Penelitian}

Variabel bebas atau variabel independen yang digunakan penelitian ini adalah kompensasi karyawan $\left(\mathrm{X}_{1}\right)$, moralitas individu $\left(\mathrm{X}_{2}\right)$, keadilan organisasi $\left(\mathrm{X}_{3}\right)$ dan sistem pengendalian intern $\left(\mathrm{X}_{4}\right)$. Sedangkan variabel terikat atau variabel dependen yang digunakan penelitian ini adalah Kecurangan (Y).

\section{Skala Pengukuran}

Skala yang digunakan adalah skala likert lima point dengan rentang 1 - 5 yang memberikan gambaran sampai seberapa jauh responden melaksanakan fungsi sesuai dengan penyataan yang diberikan (Sugiyono, 2016:93).

\section{Hipotesis Penelitian}

Pengujian hipotesis bertujuan untuk mengetahui pengaruh kompensasi karyawan, moralitas individu, keadilan organisasi dan sistem pengendalian intern terhadap kecurangan. Adapun hipotesis yang akan diuji adalah sebagai berikut :

1) Ho1 : Kompensasi karyawan tidak berpengaruh terhadap kecurangan.

2) Ha1 : Kompensasi karyawan berpengaruh terhadap kecurangan. 
3) Ho2: Moralitas individu tidak berpengaruh terhadap kecurangan.

4) Ha2 : Moralitas individu berpengaruh terhadap kecurangan.

5) Ho3 : Keadilan organisasi tidak berpengaruh terhadap kecurangan.

6) Ha3 : Keadilan organisasi bepengaruh terhadap kecurangan.

7) Ho4 : Sistem pengendalian intern tidak berpengaruh terhadap kecurangan.

8) Ha4 : Sistem pengendalian intern berpengaruh terhadap kecurangan.

9) Ho5 : Kompensasi karyawan, moralitas individu, keadilan organisasi dan sistem pengendalian intern tidak berpengaruh simultan terhadap kecurangan.

10) Ha5 : Kompensasi karyawan, moralitas individu, keadilan organisasi dan sistem

pengendalian intern berpengaruh simultan terhadap kecurangan.

\section{Metode Analisis Data dan Hipotesis}

Metode statistika yang digunakan dalam menguji data dan hipotesis dalam penelitian ini dilakukan dengan menggunakan program aplikasi IBM Statistic Program Social Science (SPSS) versi 22.0. Sebelum analisis data, terlebih dahulu dilakukan uji validitas dan reliabilitas data, kemudian uji asumsi klasik ( normalitas, multikolonieritas, heteroskedastisitas, dan autokorelasi). Uji hipotesis dilakukan dengan uji t, uji F dan koefisien determinasi.

\section{ANALISIS HASIL DAN PEMBAHASAN}

Kuesioner yang disebar berjumlah 50 kuesioner dan jumlah kuesioner yang kembali dan dapat diolah adalah sebanyak 49 kuesioner. Dengan menggunakan 49 kuesioner yang kembali, peneliti menyimpulkan bahwa kuesioner tesebut telah layak untuk diolah dan untuk selanjutnya dilakukan penelitian. Tabel berikut, menunjukkan analisis statistic deskriptif yang menggambarkan nilai maksimum, minimum, rata-rata dan standar deviasi variable penelitian.

\section{Analisis Statistik Deskriptif}

\section{Hasil Uji Statistik Deskriptif}

Descriptive Statistics

\begin{tabular}{|l|r|r|r|r|r|r|}
\hline & $\mathrm{N}$ & Minimum & Maximum & \multicolumn{2}{|c|}{ Mean } & Std. Deviation \\
\cline { 2 - 7 } & & & & & \\
& Statistic & Statistic & Statistic & Statistic & Str. & \multicolumn{1}{c|}{ Error } \\
\hline Total_Kompensasi_Karyawan & 49 & 33 & 50 & 41,71 &, 595 & 4,163 \\
Total_Moralitas_Individu & 49 & 29 & 40 & 34,53 &, 360 & 2,517 \\
Total_Keadilan_Organisasi & 49 & 32 & 50 & 39,20 &, 643 & 4,500 \\
Total_Sistem_Pengendalian_Intern & 49 & 32 & 44 & 36,53 &, 412 & 2,887 \\
Total_Kecurangan & 49 & 33 & 50 & 41,65 &, 545 & 3,816 \\
Valid N (listwise) & 49 & & & & & \\
\hline
\end{tabular}

Sumber Data : Hasil Output SPSS 22.0

\section{Uji Validitas}

Pengujian validitas data dimaksudkan untuk mengetahui apakah data yang terkumpul dari responden telah memenuhi kreteria sebagai alat ukur yang tepat.

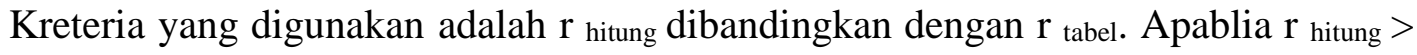
$\mathrm{r}$ tabel disimpulkan bahwa instrumen tersebut dianggap valid. Uji validitas ini

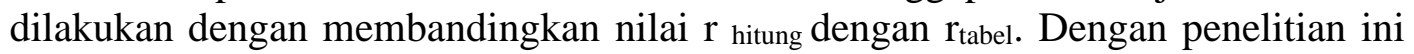


$\mathrm{df}=\mathrm{n}-2$ dimana $\mathrm{n}=49 \mathrm{df}=49-2=47$ dengan $\square 0,05 \mathrm{r}_{\text {tabel }}$ sebesar 0,2816. Hasil uji validitas untuk variable penelitian, disajikan pada table berikut.

\section{Tabel}

\section{Hasil Uji Validitas Variabel Penelitian}

Item - Total Statistics

\begin{tabular}{|l|r|c|c|c|}
\hline \multicolumn{1}{|c|}{ Variabel Penelitian } & $\begin{array}{c}\text { Corrected Item-Total } \\
\text { Correlation }\end{array}$ & r- tabel & N of Items & Keterangan \\
\hline Kompensasi Karyawan $\left(\mathrm{X}_{1}\right)$ & $.322 \mathrm{~s} / \mathrm{d} 771$ &, 2816 & 10 & Valid \\
\hline Moralitas Individu $\left(\mathrm{X}_{2}\right)$ & $.309 \mathrm{~s} / \mathrm{d} .515$ &, 2816 & 9 & Valid \\
\hline Keadilan Organisasi $\left(\mathrm{X}_{3}\right)$ & $.314 \mathrm{~s} / \mathrm{d} .710$ &, 2816 & 10 & Valid \\
\hline Sistem Pengendalian Intern $\left(\mathrm{X}_{4}\right)$ & $.359 \mathrm{~s} / \mathrm{d} 612$ &, 2816 & 9 & Valid \\
\hline Kecurangan $(\mathrm{Y})$ & $.417 \mathrm{~s} / \mathrm{d} 732$ &, 2816 & 10 & Valid \\
\hline
\end{tabular}

Sumber Data : Hasil Output SPSS 22.0

Berdasarkan hasil pengujian validitas variabel penelitian menjelaskan bahwa nilai Corrected Item-Total Correlation ( $\mathrm{r}$ hitung) yang dihasilkan untuk masingmasing variable dan butir pernyataan, nilainya lebih besar dari $r$ tabel yaitu 0,2816 , sehingga dapat disimpulkan bahwa semua variable penelitian dinyatakan valid.

\section{Uji Reliabilitas}

Uji reliabilitas digunakan untuk menunjukkan akurasi, ketepatan dan konsistensi kuesioner dalam mengukur variabel. Suatu variabel dikatakan reliable apabila memberikan nilai Cronbach's Alpha > 0,70. Aturan dalam uji ini adalah sebagai berikut :

a. Jika nilai Cronbach's Alpha > 0,70 maka dapat dikatakan reliable.

b. Jika nilai Cronbach's Alpha $<0,70$ maka dapat dikatakan reliable.

\section{Tabel}

Hasil Uji Reliabilitas

Reliability Statistics

\begin{tabular}{|c|c|c|c|c|}
\hline Variabel Penelitian & Cronbach's Alpha & $\begin{array}{c}\text { Batas } \\
\text { Signifikansi }\end{array}$ & N of Items & Keterangan \\
\hline Kompensasi Karyawan $\left(\mathrm{X}_{1}\right)$ &, 825 &, 70 & 10 & Reliabel \\
\hline Moralitas Individu $\left(\mathrm{X}_{2}\right)$ &, 721 &, 70 & 9 & Reliabel \\
\hline Keadilan Organisasi $\left(\mathrm{X}_{3}\right)$ &, 856 &, 70 & 10 & Reliabel \\
\hline Sistem Pengendalian Intern $\left(\mathrm{X}_{4}\right)$ &, 777 &, 70 & 9 & Reliabel \\
\hline Kecurangan $(\mathrm{Y})$ &, 839 &, 70 & 10 & Reliabel \\
\hline
\end{tabular}

Sumber Data : Hasil Output SPSS 22.0

Berdasarkan hasil pengujian reliabilitas variabel Kompensasi Karyawan $\left(\mathrm{X}_{1}\right)$, Moralitas Individu $\left(\mathrm{X}_{2}\right)$, Keadilan Organisasi $\left(\mathrm{X}_{3}\right)$, Sistem Pengendalian Intern $\left(\mathrm{X}_{4}\right)$ dan Kecurangan (Y) menunjukkan Cronbach's Alpha > 0,70. Hal ini dapat disimpulkan bahwa pernyataan-pernyataan dalam masing-masing variabel adalah reliable, yang berarti bahwa hasil pengukuran variabel adalah konsisten.

\section{Uji Asumsi Klasik}

\section{a. Uji Normalitas}


Uji normalitas bertujuan untuk menguji apakah dalam model regresi, variabel pengganggu atau residual memiliki distribusi normal. Uji normalitas data dapat dilakukan dengan menggunakan One Sample Kolmogorov Smirnov Test pada kolom Asymp Sig (2-tailed) yaitu jika p value (sig) > 0,05 berarti model berdistribusi normal, seperti pada table berikut .

\section{Tabel}

Hasil Uji Normalitas

One-Sample Kolmogorov-Smirnov Test

\begin{tabular}{|c|c|c|}
\hline & & $\begin{array}{l}\text { Unstandardized } \\
\text { Residual }\end{array}$ \\
\hline \multicolumn{2}{|l|}{$\mathrm{N}$} & 49 \\
\hline \multirow[t]{2}{*}{ Normal Parameters ${ }^{\mathrm{a}, \mathrm{b}}$} & Mean & ,0000000 \\
\hline & Std. Deviation & 2,17507449 \\
\hline \multirow[t]{2}{*}{ Most Extreme Differences } & Absolute &, 104 \\
\hline & $\begin{array}{l}\text { Positive } \\
\text { Negative }\end{array}$ & $\begin{array}{r}, 104 \\
-, 060\end{array}$ \\
\hline Test Statistic & & ,104 \\
\hline Asymp. Sig. (2-tailed) & & ,200 c,d \\
\hline
\end{tabular}

a. Test distribution is Normal.

b. Calculated from data.

c. Lilliefors Significance Correction.

d. This is a lower bound of the true significance.

\section{Sumber Data : Hasil Output SPSS 22.0}

Uji Normalitas juga dapat dilakukan dengan metode normal probality plot, jika data menyebar disekitar garis diagonal dan mengikuti arah garis diagonal, maka model regresi memenuhi asumsi normalitas, seperti pada gambar berikut.

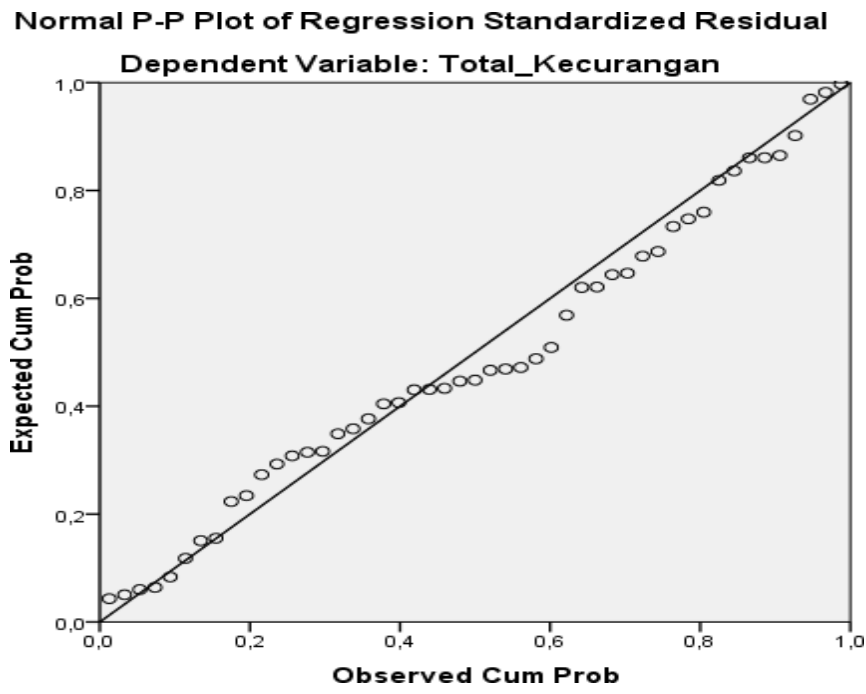

Gambar

Hasil Uji Normalitas Grafik P-Plot

Sumber Data : Hasil Output SPSS 22.0

\section{Uji Multikolonieritas}

Uji multikolonieritas digunakan untuk menguji apakah model regresi ditemukan adanya korelasi antar variabel bebas atau variabel independen. Untuk 
menguji adanya multikolonieritas dapat dilihat dari nilai tolerance dan Varian Inflation Factor (VIF). Berdasarkan nilai tolerance, nilai yang terbentuk harus di atas 0,10 dan bila menggunakan VIF, nilai yang terbentuk harus kurang dari 10 . Untuk mengetahui ada atau tidaknya multikolonieritas dalam model regresi dapat dilihat pada hasil pengujian sebagai berikut :

\section{Tabel}

\section{Hasil Uji Multikolonieritas}

Coefficients $^{\mathrm{a}}$

\begin{tabular}{|c|c|c|c|c|c|c|c|c|}
\hline \multirow{2}{*}{\multicolumn{2}{|c|}{ Model }} & \multicolumn{2}{|c|}{$\begin{array}{l}\text { Unstandardized } \\
\text { Coefficients }\end{array}$} & \multirow{2}{*}{$\begin{array}{c}\begin{array}{c}\text { Stand } \\
\text { ardize } \\
d \\
\text { Coeffic } \\
\text { ients }\end{array} \\
\text { Beta }\end{array}$} & \multirow[b]{2}{*}{$\mathrm{t}$} & \multirow[b]{2}{*}{ Sig. } & \multicolumn{2}{|c|}{ Collinearity Statistics } \\
\hline & & B & $\begin{array}{l}\text { Std. } \\
\text { Error }\end{array}$ & & & & Tolerance & VIF \\
\hline \multirow[t]{5}{*}{1} & (Constant) & $-9,401$ & 5,819 & & $-1,616$ &, 113 & & \\
\hline & Total_Kompensasi_Karyawan & ,391 &, 086 & ,427 & 4,548 &, 000 & 839 & 1,192 \\
\hline & Total_Moralitas_Individu & ,302 & 138 & 199 & 2,192 & ,034 & 893 & 1,120 \\
\hline & Total_Keadilan_Organisasi & ,169 & ,080 & ,199 & 2,104 & ,041 & ,826 & 1,210 \\
\hline & Total_Sistem_Pengendalian_Intern & 484 & 130 & ,366 & 3,713 & ,001 & ,758 & 1,320 \\
\hline
\end{tabular}

a. Dependent Variable: Total_Kecurangan

Sumber Data : Hasil Output SPSS 22.0

Berdasarkan hasil pengujian dapat diketahui bahwa nilai Tolerance keempat variabel Kompensasi Karyawan, Moralitas Individu, Keadilan Organisasi dan Sistem Pengendalian Intern adalah 0 0,10 dan nilai Variance Inflation Factor (VIF) $\square$ dari 10, sehingga dapat disimpulkan bahwa antar variabel independen tidak terjadi multikolonieritas.

\section{Uji Heteroskedastisitas}

Uji heteroskedastisitas bertujuan untuk menguji apakah dalam model regresi terjadi ketidaksamaan antara varian dari residual satu pengamatan ke pengamatan lain tetap. Ada tidaknya heteroskedastisitas dalam persamaan regresi dapat dideteksi dengan menggunakan uji glejser. Jika probablitas signifikannya di atas tingkat kepercayaan yaitu 5\% atau 0,05 maka dapat disimpulkan tidak terjadi heteroskedastisitas.

\section{Tabel}

\section{Hasil Uji Heterokedastisitas}

Coefficients

\begin{tabular}{|c|c|c|c|c|c|c|}
\hline \multirow{2}{*}{\multicolumn{2}{|c|}{ Model }} & \multicolumn{2}{|c|}{$\begin{array}{l}\text { Unstandardized } \\
\text { Coefficients }\end{array}$} & \multirow{2}{*}{$\begin{array}{c}\begin{array}{c}\text { Standardized } \\
\text { Coefficients }\end{array} \\
\text { Beta }\end{array}$} & \multirow[b]{2}{*}{$\mathrm{T}$} & \multirow[b]{2}{*}{ Sig. } \\
\hline & & $\mathrm{B}$ & Std. Error & & & \\
\hline \multirow[t]{5}{*}{1} & (Constant) & $-2,707$ & 3,454 & &,- 784 &, 437 \\
\hline & Total_Kompensasi_Karyawan & ,011 &, 051 & ,034 &, 221 & ,826 \\
\hline & Total Moralitas Individu & ,206 &, 082 & ,370 & 2,521 & ,415 \\
\hline & Total_Keadilan_Organisasi & ,014 &, 048 &, 045 & ,295 & ,769 \\
\hline & Total_Sistem_Pengendalian_Intern &,- 104 &, 077 &,- 214 & $-1,342$ & 187 \\
\hline
\end{tabular}

a. Dependent Variable: Abs_Res

Sumber Data : Hasil Output SPSS 22.0 
Hasil Uji Heteroskedastisitas - Scatterplot dapat juga dilihat pada gambar sebagai berikut, dimana titik-titik menyebar di atas dan di bawah sumbu 0, dan tidak membentuk pola tertentu, dapat disimpulkan tidak terjadi heteroskedastisitas.

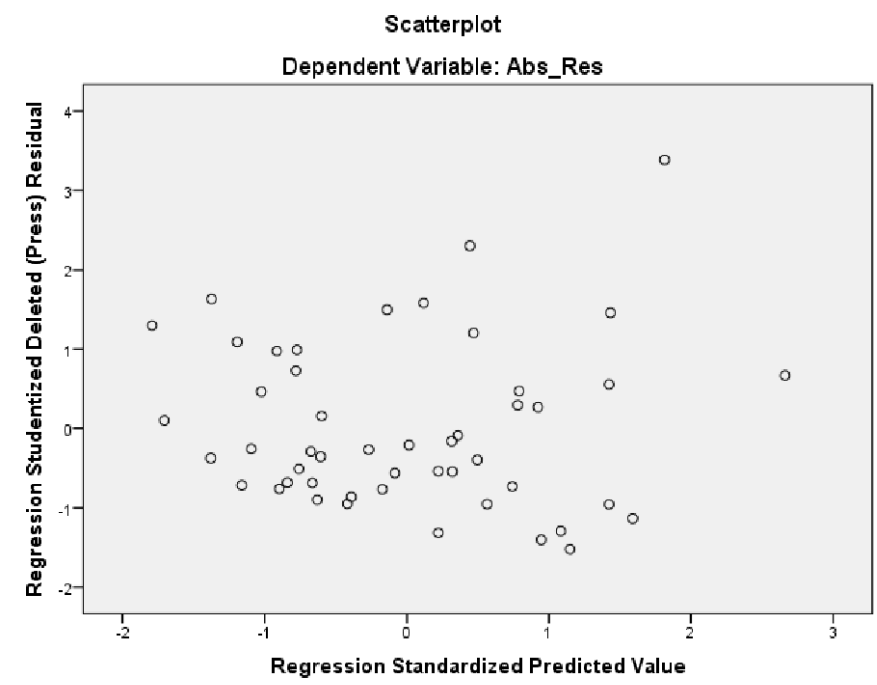

Gambar

Hasil Uji Heteroskedastisitas - Scatterplot Sumber Data : Output SPSS 22.0

\section{Uji Autokorelasi}

Uji autokorelasi bertujuan untuk menguji apakah dalam model regresi linear ada korelasi antara kesalahan pengganggu pada periode $t$ dengan kesalahan pengganggu pada periode t-1 (sebelumnya). Untuk mendeteksi ada tidaknya autokorelasi digunakan uji Durbin-Watson. Berdasarkan tabel statistic DurbinWatson, dengan signifikansi 0,05 dan jumlah data $(\mathrm{n})=49$, serta $\mathrm{k}=4$ (k adalah jumlah variabel independen) sehingga didapatkan nilai dL sebesar 1,3701 dan nilai dU sebesar 1,7210 dan untuk mengetahui apakah terdapat autokorelasi pada model regresi, maka dapat dilihat pada hasil pengujian sebagai berikut :

\section{Tabel}

\section{Hasil Uji Autokorelasi}

\begin{tabular}{|c|c|c|c|c|c|}
\hline \multicolumn{6}{|c|}{ Model Summary ${ }^{b}$} \\
\hline Model & $\mathrm{R}$ & R Square & $\begin{array}{l}\text { Adjusted R } \\
\text { Square }\end{array}$ & $\begin{array}{l}\text { Std. Error of the } \\
\text { Estimate }\end{array}$ & Durbin-Watson \\
\hline 1 &, $822^{a}$ &, 675 & ,646 & 2,272 & 2,153 \\
\hline \multicolumn{6}{|c|}{$\begin{array}{l}\text { a. Predictors: (Constant), Total_Sistem_Pengendalian_Intern, Total_Moralitas_Individu, } \\
\text { Total_Kompensasi_Karyawan, Total_Keadilan_Organisasi } \\
\text { b. Dependent Variable: Total_Kecurangan }\end{array}$} \\
\hline umbe & : Outp & SPSS 22 & & & \\
\hline
\end{tabular}

Dari hasil Uji Autokorelasi didapatkan nilai Durbin-Watson yang dihasilkan dari model regresi adalah 2,153 terletak diantara dU atau 1,7210 dan 4 - dU atau 2,2790. Dapat disimpulkan $\mathrm{dU}<\mathrm{d}<4-\mathrm{dU}=1,7210<2,153<2,2790$ maka hipotesis nol diterima yang berarti tidak ada autokorelasi, positif atau negatif. 


\section{Teknik Analisis Data}

\section{Analisis Korelasi}

Analisis korelasi bertujuan untuk mengukur kekuatan asosiasi (hubungan linier antara dua variabel. Hasil pengujian analisis korelasi adalah sebagai berikut :

\section{Tabel}

\section{Hasil Analisis Korelasi}

\section{Correlations}

\begin{tabular}{|c|c|c|c|c|c|c|}
\hline & & $\begin{array}{c}\text { Total_Kompe } \\
\text { nsasi_Karya } \\
\text { wan }\end{array}$ & $\begin{array}{c}\text { Total_Moral } \\
\text { itas_Individ } \\
\mathrm{u}\end{array}$ & $\begin{array}{c}\text { Total_Kea } \\
\text { dilan_Orga } \\
\text { nisasi }\end{array}$ & $\begin{array}{c}\text { Total_Sist } \\
\text { em_Peng } \\
\text { endalian_l } \\
\text { ntern }\end{array}$ & $\begin{array}{l}\text { Total_Ke } \\
\text { curangan }\end{array}$ \\
\hline $\begin{array}{l}\text { Total_Kompensasi_Karyaw } \\
\text { an }\end{array}$ & $\begin{array}{l}\text { Pearson } \\
\text { Correlation } \\
\text { Sig. (2-tailed) } \\
\mathrm{N}\end{array}$ & 1 & $\begin{array}{r}, 144 \\
, 324 \\
49\end{array}$ & $\begin{array}{r}, 160 \\
, 272 \\
49\end{array}$ & $\begin{array}{r}, 396^{* *} \\
, 005 \\
49\end{array}$ & $\begin{array}{r}, 632^{* *} \\
, 000 \\
49\end{array}$ \\
\hline Total_Moralitas_Individu & $\begin{array}{l}\text { Pearson } \\
\text { Correlation } \\
\text { Sig. (2-tailed) } \\
\mathrm{N}\end{array}$ & $\begin{array}{r}, 144 \\
, 324 \\
49\end{array}$ & $\begin{array}{r}1 \\
49\end{array}$ & $\begin{array}{r}, 303^{*} \\
, 034 \\
49\end{array}$ & $\begin{array}{r}, 207 \\
, 154 \\
49\end{array}$ & $\begin{array}{r}, 397^{* *} \\
, 005 \\
49\end{array}$ \\
\hline Total_Keadilan_Organisasi & $\begin{array}{l}\text { Pearson } \\
\text { Correlation } \\
\text { Sig. (2-tailed) } \\
\text { N }\end{array}$ & $\begin{array}{r}, 160 \\
, 272 \\
49\end{array}$ & $\begin{array}{r}, 303^{*} \\
034 \\
49\end{array}$ & $\begin{array}{r}1 \\
49\end{array}$ & $\begin{array}{r}, 343^{*} \\
, 016 \\
49\end{array}$ & $\begin{array}{r}, 453^{* *} \\
, 001 \\
49\end{array}$ \\
\hline $\begin{array}{l}\text { Total_Sistem_Pengendalia } \\
\text { n_Intern }\end{array}$ & $\begin{array}{l}\text { Pearson } \\
\text { Correlation } \\
\text { Sig. (2-tailed) } \\
\mathrm{N}\end{array}$ & $\begin{array}{r}, 396^{* *} \\
, 005 \\
49 \\
\end{array}$ & $\begin{array}{r}, 207 \\
, 154 \\
49\end{array}$ & $\begin{array}{r}, 343^{*} \\
, 016 \\
49\end{array}$ & $\begin{array}{r}1 \\
49 \\
\end{array}$ & $\begin{array}{r}, 645^{* *} \\
, 000 \\
49\end{array}$ \\
\hline Total_Kecurangan & $\begin{array}{l}\text { Pearson } \\
\text { Correlation } \\
\text { Sig. (2-tailed) } \\
\mathrm{N}\end{array}$ & $\begin{array}{r}, 632^{* \star} \\
, 000 \\
49\end{array}$ & $\begin{array}{r}, 397^{* *} \\
005 \\
49\end{array}$ & $\begin{array}{r}, 453^{* \star} \\
001 \\
49\end{array}$ & $\begin{array}{r}, 645^{* *} \\
, 000 \\
49\end{array}$ & $\begin{array}{r}1 \\
49\end{array}$ \\
\hline
\end{tabular}

${ }^{* *}$. Correlation is significant at the 0.01 level (2-tailed).

*. Correlation is significant at the 0.05 level (2-tailed).

Sumber Data : Hasil Output SPSS 22.0

Berdasarkan tabel 4.17, dapat disimpulkan bahwa hubungan masing-masing variabel penelitian yaitu sebagai berikut :

- Hubungan Kompensasi Karyawan $\left(\mathrm{X}_{1}\right)$ terhadap Kecurangan (Y) diperoleh hasil sebesar 0,632 dengan signifikansi sebesar 0,000<0,05. Angka ini menunjukkan bahwa Kompensasi Karyawan memiliki korelasi yang cukup kuat sebesar 63,2\% terhadap Kecurangan.

- Hubungan Moralitas Individu $\left(\mathrm{X}_{2}\right)$ terhadap Kecurangan (Y) diperoleh hasil sebesar 0,397 dengan signifikansi sebesar 0,005 < 0,05. Angka ini menunjukkan bahwa Moralitas Individu memiliki korelasi yang lemah sebesar 39,7\% terhadap Kecurangan.

- Hubungan Keadilan Organisasi $\left(\mathrm{X}_{3}\right)$ terhadap Kecurangan (Y) diperoleh hasil sebesar 0,453 dengan signifikansi sebesar 0,001 < 0,05. Angka ini menunjukkan bahwa Keadilan Organisasi memiliki korelasi yang cukup kuat sebesar 45,3\% terhadap Kecurangan.

- Hubungan Sistem Pengendalian Intern $\left(\mathrm{X}_{4}\right)$ terhadap Kecurangan (Y) diperoleh hasil sebesar 0,645 dengan signifikansi sebesar 0,000 $<0,05$. Angka ini menunjukkan bahwa Sistem Pengendalian Intern memiliki korelasi yang cukup kuat sebesar 64,5\% terhadap Kecurangan. 


\section{Analisis Regresi Linier Berganda}

Uji regresi berganda adalah hubungan secara linear antara dua atau lebih variabel independen dengan variabel dependen. Bertujuan untuk memprediksi besar variabel dependen dengan menggunakan data variabel independen yang sudah diketahui besarnya, Hasil pengujian regresi linier berganda dapat dilihat pada tabel sebagai berikut :

Tabel

Hasil Uji Regresi Linier Berganda

Coefficients $^{\mathrm{a}}$

\begin{tabular}{|c|c|c|c|c|c|c|}
\hline \multirow{2}{*}{\multicolumn{2}{|c|}{ Model }} & \multicolumn{2}{|c|}{$\begin{array}{l}\text { Unstandardized } \\
\text { Coefficients }\end{array}$} & \multirow{2}{*}{$\begin{array}{c}\begin{array}{c}\text { Standardized } \\
\text { Coefficients }\end{array} \\
\text { Beta }\end{array}$} & \multirow[b]{2}{*}{$\mathrm{t}$} & \multirow[b]{2}{*}{ Sig. } \\
\hline & & B & Std. Error & & & \\
\hline \multirow[t]{5}{*}{1} & (Constant) & $-9,401$ & 5,819 & & $-1,616$ &, 113 \\
\hline & Total_Kompensasi_Karyawan & ,391 & ,086 & ,427 & 4,548 & ,000 \\
\hline & Total_Moralitas_Individu & ,302 & ,138 & , 199 & 2,192 & ,034 \\
\hline & Total_Keadilan_Organisasi &, 169 & ,080 & , 199 & 2,104 &, 041 \\
\hline & Total_Sistem_Pengendalian_Intern & ,484 &, 130 & ,366 & 3,713 &, 001 \\
\hline
\end{tabular}

a. Dependent Variable: Total_Kecurangan

Sumber Data : Hasil Output SPSS 22.0 berikut :

Berdasarkan tabel di atas maka dapat dianalisis model estimasi sebagai

$$
\begin{gathered}
Y=\alpha+\beta 1 X_{1}+\beta 2 X_{2}+\beta 3 X_{3}+\beta 4 X_{4}+\varepsilon \text { atau } \\
Y=-9,401+0,391 X_{1}+0,302 X_{2}+0,169 X_{3}+0,484 X_{4}+\varepsilon
\end{gathered}
$$

Keterangan :

$\mathrm{Y}:$ Kecurangan.

$\alpha:$ Konstanta.

$\beta$ : Koefisien regresi (menunjukkan angka peningkatan atau penurunan variabel dependen yang didasarkan pada hubungan nilai variabel independen)

$\mathrm{X}_{1}$ : Kompensasi Karyawan.

$\mathrm{X}_{2}$ : Moralitas Individu.

$\mathrm{X}_{3}$ : Keadilan Organisasi.

$\mathrm{X}_{4}$ : Sistem Pengendalian Intern.

$\varepsilon$ : Standar Error.

Dari persamaan di atas dapat dijelaskan bahwa :

1. Nilai konstanta $(\alpha)-9,401$ menunjukkan besarnya variabel independen (kompensasi karyawan, moralitas individu, keadilan organisasi dan sistem pengendalian intern) adalah konstan, maka kecurangan cenderung menurun sebesar 9,401 menunjukkan nilai murni dari variabel kecurangan (dependen) tanpa dipengaruhi oleh variabel independen.

2. Koefisien regresi kompensasi karyawan $\left(\mathrm{X}_{1}\right)$ sebesar 0,391 berarti setiap peningkatan satu satuan variabel kompensasi karyawan, maka akan meningkatkan kecurangan sebesar 0,391 dengan asumsi variabel moralitas individu, keadilan organisasi dan sistem pengendalian intern adalah konstan.

3. Koefisien regresi moralitas individu $\left(\mathrm{X}_{2}\right)$ sebesar 0,302 berarti setiap peningkatan satu satuan variabel moralitas individu, maka akan meningkatkan kecurangan sebesar 0,302 dengan asumsi variabel kompensasi karyawan, keadilan organisasi dan sistem pengendalian intern adalah konstan. 
4. Koefisien regresi keadilan organisasi $\left(\mathrm{X}_{3}\right)$ sebesar 0,169 berarti setiap peningkatan satu satuan variabel keadilan organisasi, maka akan meningkatkan kecurangan sebesar 0,169 dengan asumsi variabel kompensasi karyawan, moralitas individu, dan sistem pengendalian intern adalah konstan.

5. Koefisien regresi sistem pengendalian intern $\left(\mathrm{X}_{4}\right)$ sebesar 0,484 berarti setiap peningkatan satu satuan variabel sistem pengendalian intern, maka akan meningkatkan kecurangan sebesar 0,484 dengan asumsi variabel kompensasi karyawan, moralitas individu, dan keadilan organisasi.

\section{Uji Hipotesis}

\section{Uji Hipotesis Secara Simultan (Uji F)}

Uji statistik $\mathrm{F}$ digunakan untuk mengetahui ada tidaknya pengaruh secara bersama-sama (simultan) variabel independen (bebas) yaitu Kompensasi Karyawan $\left(\mathrm{X}_{1}\right)$, Moralitas Individu $\left(\mathrm{X}_{2}\right)$, Keadilan Organisasi $\left(\mathrm{X}_{3}\right)$ dan Sistem Pengendalian Intern $\left(\mathrm{X}_{4}\right)$ terhadap variabel dependen (terikat) yaitu kecurangan (Y). Uji $\mathrm{F}$ dilakukan dengan cara membandingkan nilai $\mathrm{F}$ hitung dengan $\mathrm{F}$ tabel pada tingkat kepercayaan $5 \%$ atau 0,05 , jika $\mathrm{F}$ hitung $>\mathrm{F}$ tabel maka Ho ditolak dan Ha diterima dimana $\mathrm{F}$ hitung diperoleh dari hasil output SPSS dalam Anova, sedangkan $\mathrm{F}$ tabel diperoleh dari (degree of freedom) df $=\mathrm{n}-\mathrm{k}-1=49-4-1=44$, df pembilang $\mathrm{k}=4$, yaitu $F$ tabel $=2,58$. Hasil output SPSS untuk $F$ hitung disajikan pada tabel sebagai berikut :

Tabel

Hasil Uji Simultan (Uji F)

ANOVA $^{a}$

\begin{tabular}{|ll|r|r|r|r|r|}
\hline Model & & Sum of Squares & Df & Mean Square & F & Sig. \\
\hline 1 & Regression & 472,016 & 4 & 118,004 & 22,864 &, $000^{\text {b }}$ \\
& Residual & 227,086 & 44 & 5,161 & & \\
& Total & 699,102 & 48 & & & \\
\hline
\end{tabular}

a. Dependent Variable: Total Kecurangan

b. Predictors: (Constant), Total_Sistem_Pengendalian_Intern, Total_Moralitas_Individu,

Total_Kompensasi_Karyawan, Total_Keadilan_Organisasi

Sumber Data : Hasil Output SPSS 22.0

Dari Tabel Uji Anova (Analysis of Variance) didapat $\mathrm{F}$ hitung sebesar 22,864 dengan tingkat signifikansi sebesar $0,000<0.05$, dimana nilai $\mathrm{F}$ hitung $(22,864)>$ nilai $\mathrm{F}$ tabel $(2,58)$ maka $\mathrm{Ha}_{5}$ diterima, dapat disimpulkan bahwa secara bersamasama ata secara simultan variabel kompensasi karyawan $\left(\mathrm{X}_{1}\right)$, moralitas individu $\left(\mathrm{X}_{2}\right)$, keadilan organisasi $\left(\mathrm{X}_{3}\right)$ dan sistem pengendalian intern $\left(\mathrm{X}_{4}\right)$ berpengaruh positif terhadap kecurangan (Y).

\section{Koefisien Determinasi (Uji Adjusted $\mathbf{R}^{\mathbf{2}}$ )}

Koefisien determinasi ( Adjusted $\mathrm{R}^{2}$ ) mengukur seberapa jauh kemampuan variabeli independen dalam menerangkan variabel dependen. Nilai koefisien determinasi adalah antara nol dan satu. Nilai $\mathrm{R}^{2}$ yang kecil berarti kemampuan variabel-variabel independen dalam menjelaskan variasi variabel dependen sangat terbatas. Nilai yang mendekati satu berarti variabel-variabel independen memberikan hampir semua informasi yang dibutuhkan untuk memprediksi variasi variabel dependen (Imam Ghozali, 2016:95). Hasil uji koefisien determinasi dapat dilihat dalam tabel sebagai berikut : 


\section{Tabel}

Hasil Uji Koefisien Determinasi $\left(\mathbf{R}^{2}\right)$ Model Summary

\begin{tabular}{|l|r|r|r|r|}
\hline Model & $\mathrm{R}$ & $\mathrm{R}$ Square & \multicolumn{1}{|c|}{$\begin{array}{c}\text { Adjusted R } \\
\text { Square }\end{array}$} & $\begin{array}{c}\text { Std. Error of the } \\
\text { Estimate }\end{array}$ \\
\hline 1 &, $822^{\mathrm{a}}$ &, 675 &, 646 & 2,272 \\
\hline
\end{tabular}

a. Predictors: (Constant), Total_Sistem_Pengendalian_Intern,

Total_Moralitas_Individu, Total_Kompensasi_Karyawān,

Total_Keadilan_Organisasi

b. Dependent Variable: Total_Kecurangan

Sumber Data : Hasil Output SPSS 22.0

Berdasarkan tabel di atas didapatkan nilai Adjusted R Square sebesar 0,646 atau sama dengan 64,6\%. Hal tersebut menunjukkan bahwa variabel Kompensasi Karyawan $\left(\mathrm{X}_{1}\right)$, Moralitas Individu $\left(\mathrm{X}_{2}\right)$, Keadilan Organisasi $\left(\mathrm{X}_{3}\right)$ dan Sistem Pengendalian Intern $\left(\mathrm{X}_{4}\right)$ berpengaruh terhadap Kecurangan (Y) sebesar 64,6\%. Sedangkan sisanya sebesar 35,4,\% dipengaruhi oleh variabel lain yang belum diteliti dalam penelitian ini. Sehingga disimpulkan bahwa hubungan antara variabel bebas dan variabel terikat cukup kuat.

\section{Uji Hipotesis Secara Parsial (Uji t)}

Uji statistik $t$ digunakan untuk mengetahui pengaruh setiap variabel bebas terhadap variabel terikat. Uji t dilakukan dengan membandingkan antara $\mathrm{t}$ hitung dengan $\mathrm{t}$ tabel., jika Jika $\mathrm{t}_{\text {hitung }}>\mathrm{t}$ tabel dapat disimpulkan bahwa terdapat pengaruh antara variabel independen terhadap variabel dependen atau sebaliknya, jika $t$ hitung $<\mathrm{t}$ tabel maka dapat disimpulkan bahwa tidak terdapat pengaruh antara variabel independen terhadap variabel dependen.

Untuk menentukan nilai $\mathrm{t}$ tabel ditentukan dengan tingkat signifikansi 5\% atau 0,05 dengan derajat kebebasan (degree of freedom) $\mathrm{df}=\mathrm{n}-\mathrm{k}-1=49-4-1=44$, df pembilang $\mathrm{k}=4(\mathrm{k})$ sehingga diperoleh untuk $\mathrm{t}$ tabel sebesar 2,01537 sedangkan untuk hasil $\mathrm{t}$ hitung dapat dilihat dari hasil output SPSS pada tabel Coeffisient sebagai berikut :

\section{Tabel}

\section{Hasil Uji t - Uji Parsial} Coefficients $^{\mathrm{a}}$

\begin{tabular}{|c|c|c|c|c|c|c|}
\hline \multirow{2}{*}{\multicolumn{2}{|c|}{ Model }} & \multicolumn{2}{|c|}{$\begin{array}{c}\text { Unstandardized } \\
\text { Coefficients }\end{array}$} & \multirow{2}{*}{$\begin{array}{c}\begin{array}{c}\text { Standardized } \\
\text { Coefficients }\end{array} \\
\text { Beta }\end{array}$} & \multirow[b]{2}{*}{$\mathrm{T}$} & \multirow[b]{2}{*}{ Sig. } \\
\hline & & $\mathrm{B}$ & Std. Error & & & \\
\hline \multirow[t]{5}{*}{1} & (Constant) & $-9,401$ & 5,819 & & $-1,616$ &, 113 \\
\hline & Total_Kompensasi_Karyawan & ,391 & ,086 & ,427 & 4,548 &, 000 \\
\hline & Total_Moralitas_Individu & ,302 & ,138 & ,199 & 2,192 & ,034 \\
\hline & Total_Keadilan_Organisasi & , 169 &, 080 & ,199 & 2,104 &, 041 \\
\hline & Total_Sistem_Pengendalian_Intern & ,484 &, 130 & ,366 & 3,713 &, 001 \\
\hline
\end{tabular}

a. Dependent Variable: Total_Kecurangan

Sumber Data : Hasil Output SPSS 22.0

Berdasarkan tabel di atas selanjutnya peneliti melakukan pengujian hipotesis sebagai berikut :

\section{- Kompensasi Karyawan Berpengaruh Positif Signifikan terhadap \\ Kecurangan}


Berdasarkan tabel Coefficients diperoleh dari $\mathrm{t}$ hitung variabel kompensasi karyawan sebesar 4,548 dengan tingkat signifikansi sebesar 0,000. Kemudian dibandingkan dengan $\mathrm{t}$ tabel sebesar 2,01537 ternyata nilai $\mathrm{t}$ hitung $(4,548)>\mathrm{t}$ tabel (2,01537), sedangkan nilai signifikansi yang dihasilkan lebih kecil dari alpha (口) yakni 0,000 $<0,05$ maka $\mathrm{Ho}_{1}$ ditolak dan $\mathrm{Ha}_{1}$ diterima, artinya bahwa kompensasi karyawan secara parsial berpengaruh positif signifikan terhadap kecurangan sebesar 0,391 atau 39,1\%.

- Moralitas Individu Berpengaruh Positif Signifikan terhadap Kecurangan Berdasarkan tabel Coefficients diperoleh dari $\mathrm{t}$ hitung variabel moralitas individu sebesar 2,192 dengan tingkat signifikansi sebesar 0,034. Kemudian dibandingkan dengan $t$ tabel sebesar 2,01537, ternyata nilai $t$ hitung $(2,192)>t$ tabel $(2,01537)$, sedangkan nilai signifikansi yang dihasilkan lebih kecil dari alpha ( $\square$ ) yakni 0,034 $<0,05$ maka $\mathrm{Ho}_{2}$ ditolak dan $\mathrm{Ha}_{2}$ diterima, artinya bahwa Moralitas Individu secara parsial berpengaruh positif signifikan terhadap kecurangan sebesar 0,302 atau 30,2\%.

- Keadilan Organisasi Berpengaruh Positif Signifikan terhadap Kecurangan

Berdasarkan tabel Coefficients diperoleh dari $\mathrm{t}$ hitung variabel keadilan organisasi sebesar 2,104 dengan tingkat signifikansi sebesar 0,041. Kemudian dibandingkan dengan $\mathrm{t}$ tabel sebesar 2,01537 ternyata nilai $\mathrm{t}$ hitung $(2,104)>\mathrm{t}$ tabel $(2,01537)$, sedangkan nilai signifikansi yang dihasilkan lebih kecil dari alpha ( $\square$ ) yakni 0,041 $<0,05$ maka $\mathrm{Ho}_{3}$ ditolak dan $\mathrm{Ha}_{3}$ diterima, artinya bahwa keadilan organisasi secara parsial berpengaruh positif signifikan terhadap kecurangan sebesar 0,169 atau 16,9\%.

- Sistem Pengendalian Intern Berpengaruh Positif Signifikan terhadap Kecurangan

Berdasarkan tabel Coefficients diperoleh dari $\mathrm{t}$ hitung variabel sistem pengendalian intern

sebesar 3,713 dengan tingkat signifikansi sebesar 0,001. Kemudian dibandingkan dengan $\mathrm{t}$ tabel sebesar 2,01537, ternyata nilai $\mathrm{t}$ hitung $(3,713)>\mathrm{t}$ tabel $(2,01537)$, sedangkan nilai signifikansi yang dihasilkan lebih kecil dari alpha ( $\square$ ) yakni 0,001 $<$ 0,05 maka $\mathrm{Ho}_{4}$ ditolak dan $\mathrm{Ha}_{4}$ diterima, artinya bahwa sistem pengendalian intern secara parsial berpengaruh positif signifikan terhadap kecurangan sebesar 0,484 atau 48,4\%.

\section{Interpretasi Hasil Penelitian}

Kompensasi Karyawan Berpengaruh Positif Signifikan terhadap Kecurangan Dengan demikian hasil penelitian ini menunjukkan bahwa semakin tinggi kompensasi yang diberikan oleh perusahaan kepada karyawan maka dapat membuat terjadinya kecurangan semakin meningkat. Begitu dengan sebaliknya apabila kompensasi yang diberikan oleh perusahaan kepada karyawan menurun maka dapat membuat terjadinya kecurangan akan menurun. Hal ini terjadi karena faktor keserakahan (greeds) yang diartikan sebagai perilaku serakah yang secara potensial ada di dalam diri setiap orang. Walaupun kompensasi karyawan yang diberikan sudah terpenuhi dengan baik, kenyataannya karyawan berpotensi melakukan kecurangan karena karyawan tersebut belum puas dengan apa yang diberikan oleh perusahaan. 
Hasil penelitian ini sejalan dengan hasil penelitian sebelumnya yang dilakukan oleh Ida Bagus Komang Suarcaya, Made Aristia Prayudi dan Nyoman Trisna Herawati (2017), Benedicta Mega Haryanti D dan Muhammad Nuryanto (2018) yang menyatakan bahwa terdapat pengaruh signifikan kompensasi karyawan terhadap kecurangan. Namun hasil penelitian ini tidak sejalan dengan hasil penelitian Deni Ahriati (2015), Adrian Bartenputra (2016), dan Fera (2018) bahwa tidak terdapat pengaruh kesesuaian kompensasi terhadap kecurangan. Perbedaan tersebut diduga karena objek penelitian yaitu pada SKPD Kota Bukit Tinggi.

\section{Moralitas Individu Berpengaruh Positif Signifikan terhadap Kecurangan}

Hasil penelitian ini menunjukkan bahwa semakin baik tingkat moral seseorang maka dapat meningkatkan terjadinya kecurangan. Begitu dengan sebaliknya apabila tingkat moral seseorang buruk maka dapat menurunkan terjadinya kecurangan. Hal ini terjadi karena faktor keserakahan (greeds) yang diartikan sebagai perilaku serakah yang secara potensial ada di dalam diri setiap orang. Tingkat moral individu yang baik belum menjamin individu tersebut tidak melakukan kecurangan, kenyataannya individu yang memiliki moral yang baik juga berpotensi melakukan kecurangan karena individu tersebut merasa belum puas terhadap apa yang diberikan oleh perusahaan.

Hasil penelitian ini sejalan dengan hasil penelitian sebelumnya yang dilakukan oleh Gede Krisna Saputra (2015), Ranti Melasari (2016) disimpulkan bahwa moralitas individu berpengaruh signifikan terhadap kecurangan (fraud). Namun hasil penelitian ini tidak sejalan dengan hasil penelitian M. Harry Krishna Mulia (2017), Nanda Amalia Agnia Salahudin (2018) dan Fera (2018) menunjukkan bahwa moralitas individu tidak berpengaruh terhadap kecenderungan kecurangan akuntansi. Perbedaan tersebut diduga karena objek penelitian yang dilakukan yaitu mahasiswa/I pada Universitas, Keuangan garment, dan bagian keuangan kantor Walikota Jakarta Barat.

\section{Keadilan Organisasi Berpengaruh Positif Signifikan terhadap Kecurangan}

Hasil penelitian ini menunjukkan bahwa semakin tinggi tingkat keadilan organisasi di dalam perusahaan maka akan meningkatkan terjadinya kecurangan. Begitu dengan sebaliknya apablia tingkat keadilan organisasi di dalam perusahaan menurun maka akan menurunkan terjadinya kecurangan. Hal ini terjadi karena faktor keserakahan (greeds) yang diartikan sebagai perilaku serakah yang secara potensial ada di dalam diri setiap orang. Karyawan yang diperlakukan secara adil ditempat mereka bekerja belum menjamin karyawan tersebut tidak melakukan kecurangan, kenyataannya karyawan berpotensi melakukan kecurangan karena karyawan tersebut belum puas dengan apa yang diberikan oleh perusahaan.

Hasil penelitian ini sejalan dengan hasil penelitian sebelumnya yang dilakukan oleh Lisa Amelia Herman (2013), Jelfani Saragih (2017) yang menunjukkan bahwa keadilan organisasi berpengaruh signifikan terhadap kecurangan. Namun hasil penelitian ini tidak sejalan dengan hasil penelitian Irmaya Sitarahmi (2016), Nanda Amalia Agnia Salahudin (2018) menunjukkan bahwa keadilan organisasional tidak berpengaruh secara signifikan terhadap kecurangan karyawan. Perbedaan tersebut diduga karena objek penelitian yang dilakukan yaitu pada Kantor Cabang Utama Bank Pemerintah dan Pada Perusahaan Gerai Minimarket di Kota Semarang. 


\section{Sistem Pengendalian Intern Berpengaruh Positif Signifikan terhadap Kecurangan}

Hasil penelitian ini menunjukkan bahwa semakin baik sistem pengendalian intern di dalam suatu perusahaan maka akan meningkatkan kecurangan. Begitu dengan sebaliknya semakin buruk sistem pengendalian intern di dalam suatu perusahaan maka akan menurunkan terjadinya kecurangan. Hal ini terjadi karena faktor keserakahan (greeds) yang diartikan sebagai perilaku serakah yang secara potensial ada di dalam diri setiap orang. Sistem pengendalian intern memiliki pengaruh yang besar terhadap kelangsungan perusahaan, dengan sistem pengendalian yang baik, maka perusahaan dapat melaksanakan seluruh aktifitasnya sesuai dengan tujuan dan sasaran yang ingin dicapai. Sistem pengendalian intern yang baik belum menjamin karyawan tidak melakukan kecurangan, kenyataannya karyawan berpotensi melakukan kecurangan karena karyawan tersebut belum puas dengan apa yang diberikan oleh perusahaan.

Hasil penelitian ini sejalan dengan hasil penelitian sebelumnya yang dilakukan oleh Lisa Amelia Herman (2013), Ranti Melasari (2016), M. Harry Krishna Mulia 2017) yang menunjukkan bahwa pengendalian internal berpengaruh signifikan terhadap kecurangan. Namun hasil penelitian ini tidak sejalan dengan hasil penelitian Deni Ahriati (2015), Nanda Amalia Agnia Salahudin (2018) menunjukkan bahwa tidak terdapat pengaruh pengendalian internal terhadap kecenderungan kecurangan akuntansi. Perbedaan tersebut diduga karena objek penelitian yang dilakukan yaitu pada Pemerintah Daerah Kabupaten Lombok Timur dan bagian keuangan Kantor Walikota Jakarta Barat.

\section{Kompensasi Karyawan, Moralitas Individu, Keadilan Organisasi dan Sistem Pengendalian Intern Berpengaruh Simultan terhadap Kecurangan.}

Berdasarkan nilai Adjusted R Squaresebesar 0,646 atau sama dengan 64,6\%. Hal tersebut menunjukkan bahwa sebesar $64,6 \%$ pengaruh Kecurangan (Y) dapat dijelaskan oleh variabel Kompensasi Karyawan $\left(\mathrm{X}_{1}\right)$, Moralitas Individu $\left(\mathrm{X}_{2}\right)$, Keadilan Organisasi $\left(\mathrm{X}_{3}\right)$ dan Sistem Pengendalian Intern $\left(\mathrm{X}_{4}\right)$. Sedangkan sisanya sebesar 35,4\% dipengaruhi oleh variabel lain yang belum diteliti dalam penelitian ini. Sehingga disimpulkan bahwa hubungan antara variabel bebas dan variabel terikat cukup kuat.

\section{KESIMPULAN DAN SARAN}

\section{Kesimpulan}

Berdasarkan hasil penelitian ini mengenai pengaruh kompensasi karyawan, moralitas individu, keadilan organisasi, dan sistem pengendalian intern terhadap kecurangan menggunakan analisis regresi linear berganda, maka dapat diambil kesimpulan sebagai berikut :

1. Hasil penelitian ini menunjukkan bahwa Kompensasi Karyawan berpengaruh positif signifikan terhadap Kecurangan.

2. Hasil penelitian ini menunjukkan bahwa Moralitas Individu berpengaruh positif signifikan terhadap Kecurangan.

3. Hasil penelitian ini menunjukkan bahwa Keadilan Organisasi berpengaruh positif signifikan terhadap Kecurangan. 
4. Hasil penelitian ini menunjukkan bahwa Sistem Pengendalian Intern berpengaruh positif signifikan terhadap Kecurangan

5. Hasil penelitian ini menunjukkan bahwa Kompensasi Karyawan, Moralitas Individu, Keadilan Organisasi dan Sistem Pengendalian Intern secara bersama-sama berpengaruh simultan terhadap Kecurangan.

\section{Saran}

Adapun saran dalam penelitian ini ada dua hal, yaitu bagi perusahaan dan bagi peneliti lanjutan, dijelaskan sebagai berikut :

\section{Bagi Perusahaan}

Adapun hasil penelitian ini menunjukkan analisis pengaruh kompensasi karyawan, moralitas individu, keadilan organisasi dan sistem pengendalian intern terhadap kecurangan, saran dari penelitian ini adalah sebagai berikut :

a. Perusahaan diharapkan dapat meningkatkan pemberian kompensasi kepada karyawannya.

b. Perusahaan diharapkan lebih memperhatikan karyawannya dengan cara memberikan arahan mengenai pemahaman kode etik perbankan dan melaksakan peraturan-peraturan yang berlaku di perusahaan.

c. Perusahaan diharapkan dapat memberikan perlakuan yang adil di dalam organisasi agar tercipta lingkungan kerja yang kondusif dan tidak ada kecemburuan antar sesama karyawan.

d. Perusahaan diharapkan dapat mempertahankan dan meningkatkan sistem pengendalian intern yang lebih baik mengingat teknologi yang digunakan pada perusahaan perbankan saat ini semakin canggih sehingga perlu adanya sistem pengendalain intern yang baik.

\section{Bagi Peneliti Lanjutan}

Peneliti selanjutnya diharapkan dapat memperbaiki kekurangan penelitian ini diantaranya sebagai berikut :

1. Peneliti selanjutnya diharapkan dapat melakukan penelitian dengan objek penelitian yang berbeda, misalnya perusahaan yang bergerak dibidang lainnya bukan hanya bidang perbankan saja.

2. Peneliti selanjutnya diharapkan dapat menambah variabel lain mengingat banyak faktor yang dapat memperngaruhi terjadinya kecurangan seperti kepuasan kerja, tekanan, asimetri informasi, kompetensi dan lainnya sebagainya.

3. Peneliti selanjutnya diharapkan dapat menambah jumlah responden dengan lingkup objek penelitan yang lebih besar dan waktu yang cukup sehingga dapat diperoleh data dan hasil analisis yang lebih akurat.

\section{DAFTAR PUSTAKA}

Ahriati, D., Basuki, P., \& Widiastuty, E. (2015). Analisis Pengaruh Sistem Pengendalian Internal, Asimetri Informasi, Perilaku Tidak Etis dan Kesesuaian Kompensasi Terhadap Kecenderungan Kecurangan Akuntansi Pada Pemerintah Daerah Kabupaten Lombok Timur. InFestasi (Jurnal Bisnis dan Akuntansi), 11(1), 41-55. 
Dibyopranoto, B. M. H \& Nuryanto M. (2018). Pengaruh Kompensasi Karyawan dan Kepuasan Kerja Terhadap Kecenderungan Kecurangan Perbankan. Jurnal. Universitas Trisakti Indonesia.

Fera (2018). Pengaruh Efektivitas Pengendalian Internal, Moralitas Individu, Kesesuaian Kompensasi, Dan Asimetri Informasi Terhadap Kecenderungan Kecurangan Akuntansi (Studi Empiris pada Karyawan Divisi Keuangan dan Garment PT. Dan Liris Kabupaten Sukoharjo) (Doctoral dissertation, Universitas Muhammadiyah Surakarta).

Ghozali, Imam. 2016. Aplikasi Analisis Multivariate Dengan Program IBM SPSS 23. Semarang: Badan Penerbit Universitas Diponogoro.

Herman, L. A. (2013). Pengaruh Keadilan Organisasi dan Sistem Pengendalian Intern Terhadap Kecurangan (Studi Empiris Pada Kantor Cabang Utama Bank Pemerintah di Kota Padang). Jurnal Akuntansi, 1(1).

Hery, 2017. Auditing Dan Asurans, Integrated And Comprehensive Edition. Jakarta: Grasindo.

Ikatan Bankir Indonesia. Profil Ikatan Bankir Indonesia. Diakses pada tanggal 11/05/2020, 22:05 WIB. https://ikatanbankir.or.id/profil-ikatan-bankir-indonesia-ibi/

Kadarisman, M. 2016. Manajemen Kompensasi. Jakarta: PT. Rajagrafindo Persada.

Melasari, R. (2016). Pengaruh Moralitas Individu dan Pengendalian Internal Terhadap Kecenderungan Kecurangan Akuntansi Pada Perbankan di Tembilahan. Jurnal Akuntansi dan Keuangan, 5(2).

Meliana, M., \& Hartono, T. R. (2019). Fraud Perbankan Indonesia: Studi Eksplorasi. In Prosiding Seminar Nasional Pakar (pp. 2-52).

Muhammad, R., \& Ibrahim, R. (2017). Pengaruh Kesesuaian Kompensasi, Penerapan Sistem Informasi Akuntansi, dan Efektivitas Pengendalian Internal Terhadap Kecurangan Akuntansi Studi Pada Bank Perkreditan Rakyat (BPR) di Kota Banda Aceh. Jurnal Ilmiah Mahasiswa Ekonomi Akuntansi, 2(4), 136-145.

Mulia, M. H. K., Febrianto, R., \& Kartika, R. (2017). Pengaruh Moralitas Individu dan Pengendalian Internal terhadap Kecurangan: Sebuah Studi Eksperimental. Journal of Accounting and Investment, 18(2), 198-208.

Priantara, Diaz. 2013. Fraud Auditing \& Investigation. Jakarta: Mitra Wacana Media.

Rahmat, A. (2018). Moralitas dan Pengendalian Internal dalam Kecenderungan Kecurangan Akuntansi (Studi Eksperimen Pada Konteks Perguruan Tinggi Negeri-BLU). Jurnal Akuntansi, 6(3).

Riduwan dan Engkos Achmad Kuncoro, 2012. Cara menggunakan dan Memakai Path Analysis (Analisis Jalur). Bandung: CV Alfabeta.

Santoso, Agus, 2012. Hukum, Moral \& Keadilan. Jakarta: Prenada Media.

Saputra, G. K., Darmawan, N. A. S., SE, A., \& Purnamawati, I. G. A. (2015). Pengaruh Pengendalian Intern Kas, Implementasi Good Governance dan Moralitas Individu Terhadap Kecurangan (Fraud) (Studi Empiris Pada LPD di Kabupaten Buleleng Bagian Timur). JIMAT (Jurnal Ilmiah Mahasiswa Akuntansi) Undiksha, 3(1).

Segoro, Waseso, 2017. Manajemen Sumber Daya Manusia: Pendekatan Teoritis dan Praktis. Yogyakarta: Deepublish. 
Setiawan, M. D., Adiputra, I. M. P., SE, S., Yuniarta, G. A., \& AK, S. (2015). Pengaruh Sistem Pengendalian Intern, Asimetri Informasi, dan Keadilan Organisasi terhadap Kecurangan (Fraud) (Studi empiris pada Bank Perkreditan Rakyat Se-Kabupaten Buleleng). JIMAT (Jurnal Ilmiah Mahasiswa Akuntansi) Undiksha, 3(1).

Sitarahmi, I. (2016). Pengaruh Keadilan Organisasional Terhadap Kecurangan dengan Variabel Moderating Kualitas Pengendalian Internal. Jurnal Ilmu Manajemen dan Akuntansi Terapan (JIMAT), 7(2), 78-89.

Suarcaya, I. B. K., Prayudi, M. A., Herawati, N. T., \& Ak, S. E. (2018). Pengaruh Kesesuaian Kompensasi, Pengendalian Internal, dan Perilaku Tidak Etis Terhadap Kecenderungan Kecurangan (Fraud) (Studi Kasus Pada Persepsi Pegawai Koperasi Simpan Pinjam (KSP) Se-kecamatan Buleleng). JIMAT (Jurnal Ilmiah Mahasiswa Akuntansi) Undiksha, 8(2).

Sugiyono, 2016. Metode Penelitian Kuantitatif, Kualitatif dan R\&D. Bandung: Alfabeta.

Sumbayak, J. S., Anisma, Y., \& Hasan, M. A. (2017). Pengaruh Keadilan Organisasi, Sistem Pengendalian Intern, Komitmen Organisasi dan Gaya Kepemimpinan Terhadap Kecurangan (Fraud) (Studi Empiris Pada Kantor Cabang Utama Perusahaan Leasing Di Kota Pekanbaru) (Doctoral Dissertation, Universitas Riau).

Wati, C., \& Puspitasari, W. (2019). Pengaruh Fraud Diamond, Corporate Governance, dan Kompleksitas Bank Terhadap Financial Statement Fraud Pada Perusahaan Perbankan. Jurnal Akuntansi Trisakti, 4(2), 157-168.

Yuliana, A., Satriawan, S., Adri, R., \& Hariyani, E. (2016). Pengaruh Keadilan Organisasi, Sistem Pengendalian Intern dan Komitmen Organisasi Terhadap Kecurangan (Fraud) (Studi Empiris Pada Kantor Cabang Utama Bank Syariah Di Kota Pekanbaru) (Doctoral Dissertation, Universitas Riau. 